\title{
A life course perspective on social protection among the working poor of Egypt
}

Maia Sieverding

Follow this and additional works at: https://knowledgecommons.popcouncil.org/departments_sbsr-pgy

Part of the Demography, Population, and Ecology Commons, and the International Public Health Commons

How does access to this work benefit you? Let us know!

\section{Recommended Citation}

Sieverding, Maia. 2012. "A life course perspective on social protection among the working poor of Egypt," Gender and Work in the MENA Region Working Paper no. 24. Cairo: Population Council. 
NUMBER 24

SEPTEMBER 2012

GENDER AND WORK IN THE MENA REGION

WORKING PAPER SERIES

Poverty, Job Quality and Labor Market Dynamics

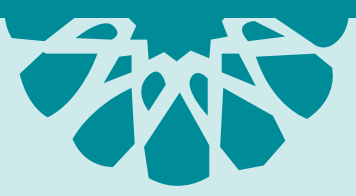

A Life Course Perspective on Social Protection among the Working Poor in Egypt

Maia Sieverding

(2) Population Council 
Maia Sieverding is a PhD student at UC Berkeley (and a former Population Council Employee). Email: msieverding@berkeley.edu

The research presented in this publication is the result of a project funded by Canada's International Development Research Centre (www.idrc.ca).

\section{IDRC * CRDI}

Canadä̀

\section{Population Council \\ Research that makes a difference}

TThe Population Council confronts critical health and development issues-from stopping the spread of HIV to improving reproductive health and ensuring that young people lead full and productive lives. Through biomedical, social science and public health research in about 50 countries, the Council works with our partners to deliver solutions that lead to more effective policies, programs, and technologies to improve lives worldwide. Established in 1952 and headquartered in New York, the Council is a nongovernmental, nonprofit organization with an international board of trustees.

Population Council

Egypt Country Office

59 Misr Helwan Agricultural Road, Maadi,

Cairo, Egypt

Tel.: (+202) 2525-5965, (+202) 2525-5967, (+202) 2525-5968

Facsimile: (+202) 2525-5962

Website: http://www.popcouncil.org

Email: pcouncil@popcouncil.org

(C) 2012 The Population Council, Inc.

Any part of this publication may be reproduced without permission for limited distribution, provided it is distributed without charge and the Population Council is acknowledged as its source. The Population Council would appreciate receiving a copy of any materials in which the text is used.

ISSN: 17930/2012 
NUMBER 24

SEPTEMBER 2012

GENDER AND WORK IN THE MENA REGION WORKING PAPER SERIES

Poverty, Job Quality and Labor Market Dynamics

\section{A Life Course Perspective on Social Protection among the Working Poor in Egypt}

Maia Sieverding 



\section{Table of content}

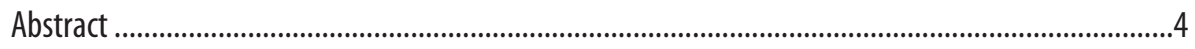

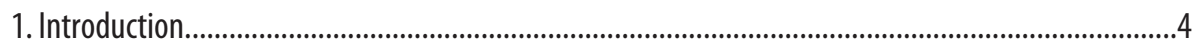

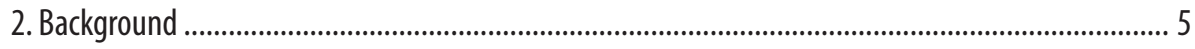

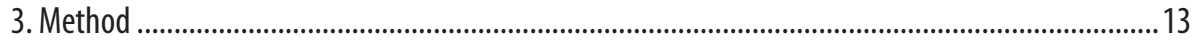

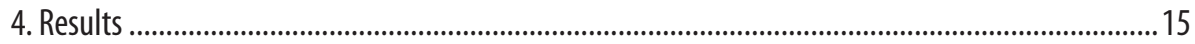

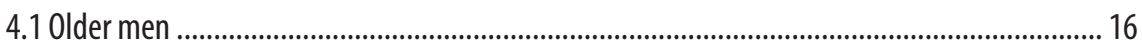

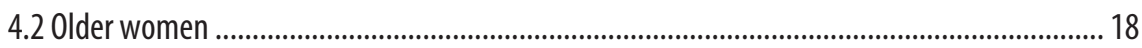

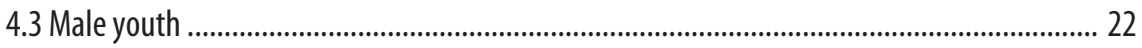

4.4 Female youth .................................................................................................................. 27

5. Discussion .............................................................................................................. 31

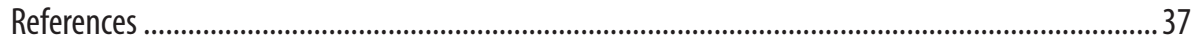




\section{Abstract}

This paper employs a generational comparison to examine how increasing labor market informality has affected how poor households in Egypt gain access to and rely on social protection schemes. Using a qualitative approach rare in research on social protection, the analysis relies on a set of 53 in-depth interviews conducted in Cairo and rural areas of Qena governorate. The interview sample was structured to enable a comparison of social protection access among young (age 20-33) and older (age 50-65) adults, and among men and women. The results indicate that among the generation of Egyptians approaching retirement, the expansion of public employment and a policy allowing easy access to survivors' benefits among female dependents served as important means of increasing social insurance coverage. However, many young households do not have even one member enrolled in the public pension system. Labor market instability and informality have also lowered the perceived value of social protection among this generation. In conclusion, the paper discusses five common points of vulnerability across the four groups studied: labor force discontinuity among workers in the private sector, women's dependence on survivor benefits, low pension values, poor quality of and limited access to health insurance, and, finally, lack of awareness of social protection mechanisms and poor understanding of how they function. All of these factors may create significant barriers to social protection access among poor households, and must be addressed if coverage rates are to be extended, or even maintained, in the future.

\section{Introduction}

Researchers and practitioners have increasingly been turning to the social protection framework as an approach to poverty alleviation in the Global South. Moving beyond the concept of the social safety net that accompanied structural adjustment programs in the I990s, social protection adopts a more integrated approach to poverty alleviation that focuses on reducing risk and vulnerability (Kabeer 2009). The social protection framework has thus developed along with increasing interest in the study of poverty dynamics, as well as non-monetary dimensions of poverty, including exclusion and insecurity (Norton et al. 2002; Barrientos et al. 2005; Barrientos and Hulme 2009). 
Despite this growing interest in social protection, little qualitative research has directly addressed how citizens of developing countries view and access different social protection mechanisms. Social protection is more often brought into qualitative work at the conclusions stage, serving as a framework for policy recommendations resulting from studies that are focused on poverty dynamics (see, for example, Davis 20II). ${ }^{\text {T This }}$ paper aims to address this gap by questioning how poor households in Egypt access different social protection schemes and how they perceive the value of those schemes. It also aims to identify key vulnerabilities in terms of gaps in social protection access for different population groups. Egypt is in interesting case in which to examine such questions during a period of economic and political change, as it is a country with extensive legal social protection mechanisms, the efficacy of which have been challenged by economic liberalization and labor market informalization. Recent political change in Egypt has also stalled existing efforts to reform the social protection system, while at the same time creating new legislative openings in a variety of areas.

The paper draws on 53 in-depth interviews conducted in a rural and an urban location. The qualitative fieldwork was structured to provide a comparison between the older generation of Egyptians approaching retirement and the younger generation of recent graduates that has faced a privatizing labor market. The findings point to several common sources of vulnerability across different generational and gender groups, including labor force discontinuity among workers in the private sector, a high level of dependence on survivor benefits among women, low pension values, and the poor quality of the public health insurance system. Finally, although trust in the public sector pension system was high, and the idea of formal social protection was valued in the abstract, low awareness of how Egypt's social protection systems actually functioned was an important barrier to access among all groups.

\section{Background}

Research on access to different social protection schemes in the Middle East and North Africa (MENA) has lagged behind other regions, notably Latin America and South Asia. However, there is a great need to address poverty and vulnerability in MENA given the difficult labor market conditions that have prevailed throughout the region over the past two

1 An important exception is Goudge et al. (2009), who examine factors affecting access to publicly provided health care services in South Africa among households with at least one chronically ill member. 
decades (see Moghadam 1998; Dhillon and Yousef, eds. 2009), and during the aftermath of the Arab Spring in particular. Egypt is no exception to these regional trends, and has struggled with high youth unemployment, growing informalization of the labor market, and low wage levels since the late 1990 s (see Assaad, ed. 2009). The national economic slowdown following the January $25^{\text {th }}$ 2OII revolution, in combination with the largescale return of migrant laborers who have been affected by other conflicts in the region, has led to further concerns over Egypt's long-term economic prospects and their implications for poverty. ${ }^{2}$

For the purposes of this paper, social protection is defined following the International Labor Organization's (ILO) rights-based approach, in which social protection is conceived of as a set of policies and programs that "protect against low or declining living standards arising out of a number of basic risks and needs" (van Ginneken 2003b, p. II, cited in Barrientos and Hulme 2009). Specifically, social protection is designed to insure against vulnerability to sudden losses of income associated with events such as health crises, disability, old age, maternity, or unemployment (ILO 2009). The life course perspective adopted in this paper is based on this conception of social protection as providing insurance against points in the individual life course and the family life cycle when populations are at their most vulnerable (Barrientos et al. 2005).

\section{The social protection system in Egypt}

Egypt, like many other countries in MENA, has an extensive social protection system in law. The ILO categorizes Egypt as having a "semicomprehensive" social security system that includes coverage in case of old age, sickness, maternity, employment injury, and unemployment, as well as survivor benefits (ILO 201O: 203). Social insurance coverage is mandatory for workers in the public and private sectors, as well as for the self-employed. For wage workers in the public and private sectors, total contribution rates for social insurance are high, reaching $4 \mathrm{I} \%$ of the basic wage and $25 \%$ of the variable wage (the latter constituting bonuses, profit shares and other forms of non-regular remuneration). These contributions are split between the worker (I4\% of the basic wage and Io\% of the variable wage), the employer ( $26 \%$ of the basic wage and $15 \%$ of the variable wage) and the government ( $\mathrm{r} \%$ of the variable wage, in addition to making up for any budget deficits) (Helmy 2008).

2 Prior to the revolution, in 2005, the poverty rate in Egypt reached $19.6 \%$ with an additional $21.0 \%$ near poor. Combining the poor and near-poor categories approximates the commonly used $\$ 2$ per day international poverty standard (World Bank 2007). 
Workers who make social insurance contributions for a minimum of I 20 months are eligible for a pension at age 60 , and those with 240 months of contributions are eligible for early retirement at any age. However, the value of this pension is calculated based on the salary level during the last two years of employment only. ${ }^{3}$ In the case of the death of a pensioner or an individual eligible for a pension, benefits may pass to the deceased's eligible survivors. The pension value is divided between eligible survivors according to a complex legal schedule; those eligible to receive benefits include widows, a widower if disabled, dependent sons and brothers under age 2I (26 if a student), unmarried sisters and daughters regardless of age, and dependent parents (SSA 2OII).

Covered workers are also eligible to receive compensation in case of disability, workplace injury and unemployment (SSA 20II). Women covered under social insurance are also legally entitled to three months of paid maternity leave for up to three children (SSA 2OII). In addition, under Egyptian labor law, women working in establishments with more than 50 employees are also entitled to up to two years of unpaid childrearing leave per child. ${ }^{4}$ Publicly-provided health insurance is legally compulsory for certain groups, including formal sector workers and pensioners, and is provided through the Health Insurance Organization (HIO). HIO operates a national network of facilities through which it provides services to those covered by health insurance (Maeda and El Saharty 2008).

Social insurance covering old age, disability and survivor benefits is also mandatory for the self-employed in Egypt (Helmy 2008). The selfemployed can self-declare their level of insurable income, with the monthly contribution set at $15 \%$ of the declared income. Pension eligibility is at age 65 with 120 months of contributions. ${ }^{5} \mathrm{~A}$ similar system exists to cover Egyptians working abroad, but for this group social insurance coverage is optional (Helmy 2008).

Egypt also has several publicly-funded social assistance schemes, which are targeted primarily towards widows, divorcees, orphans, invalids and the aged. However, as discussed further below, social assistance programs do not reach the majority of Egypt's poor, and for those who do receive assistance, the amounts are very small (Loewe 2004).

3 Under certain circumstances, for private sector employees the pension may be calculated based on the five years of wages prior to the last two years before retirement. For public sector employees, the pension is always calculated based on the last two years (SSA 2011).

4 Labor law Number 12 of 2003, available at http://www.egypt.gov.eg/english/laws/pdf/Book2.pdf

5 Law 108 of 1976. 


\section{Coverage of the social protection system}

The ILO (2009) has also noted that most countries in the MENA region lack a comprehensive, coordinated social protection policy, an assessment that applies well to Egypt despite its fairly extensive legal social protection system. Egypt's social protection system suffers from lack of efficacy, particularly in terms of poor coordination between systems, the failure to reach many population groups in need, and the unequal distribution of benefits among groups that do receive them (Loewe 2004; World Bank 2006). These weaknesses have contributed both to shaping the current distribution social protection coverage and to the challenges Egypt faces in maintaining or expanding coverage in the future.

Although social assistance has come to play a particularly prominent role in discourse and practice as a means to extend social protection to the poorest populations in the Global South (ILO 20IO; Barrientos 2OII), in Egypt social insurance has thus far been a much more common means of accessing social protection. Among the current generation of older households in which the head is age 60 or above, $63.4 \%$ were receiving a public contributory (social insurance) pension as of 2006, whereas only $\mathbf{1 2 . 7 \%}$ were receiving a public non-contributory (social assistance) pension. Receipt of non-contributory pensions is concentrated among female-headed households, of whom $15.6 \%$ were receiving a pension in 2006, compared to $4.4 \%$ of male-headed households. Non-contributory pensions are also more prevalent in rural areas, where poverty rates are higher than in urban ones. ${ }^{6}$ However, overall the World Bank estimates that public social assistance reaches less than I2\% of Egypt's poor (2006: 35 ).

The important role of social insurance in providing social protection coverage in Egypt is a result of public employment policies put in place during the early I960s that guaranteed government jobs to all graduates of vocational secondary, vocational post-secondary, and university education. This policy led to a prominent role for the government in national employment, particularly among women; the public sector quickly came to define the standard for a family-friendly, socially acceptable job (Barsoum 2004; Assaad 2007). As public sector employees enjoy a particularly privileged position in Egypt's social protection system, receiving pension, health, injury, maternity and unemployment benefits (Loewe 2004), the expansion of public employment played a significant role in expanding social protection. However, in the early I990s, Egypt began implementing a structural adjustment program that precipitated a significant decline in public sector hiring. Achieving full social protection coverage through the labor market - or even maintaining current levels of coverage - thus faces several challenges moving forward.

6 Author's calculations based on the 2006 Egypt Labor Market Panel Survey (ELMPS). 
First, labor force participation among women in Egypt is low and, among some groups, declining. Only $26.9 \%$ of Egyptian women were engaged in market work in 2006. Of those, $45 \%$ were engaged in non-wage work, which typically takes place in a family setting and is unlikely to provide benefits (Assaad and El Hamidi 2009: 224, 227). Women have also been particularly hard-hit by the reduction in public sector hiring, and appear to be withdrawing from the labor force rather than accepting jobs in the private sector. Employment-to-population ratios among women declined over the period from 1988 to 2006 for all levels of education for which the public employment guarantees used to apply (Assaad and El Hamidi 2009: 234). This means that a large percentage of the female population in Egypt is not directly covered by contributory pensions, placing them in the more vulnerable position of reliance on social assistance, shared family benefits, or survivor benefits in order to access social protection. Although the assumption that women will gain access to social protection through extended family structures is built into many national social protection systems, this is not necessarily the ideal mechanism for reducing women's vulnerability (Sabates-Wheeler and Kabeer 2003).

Second, the decline in public sector hiring has largely been made up for through growth in Egypt's informal economy. The public sector shrank from 39 percent of total employment in 1998 to 30 percent in 2006. The private formal sector, while growing fairly rapidly since the late I990s, has not been able to absorb the number of workers who were once tracked into government employment. During the same period, informal employmentdefined as employment without a contract or social insurance registration - has thus increased from $57 \%$ of total employment in 1998 to $61 \%$ in 2006 (Assaad 2009). ${ }^{7}$ Like many developing countries, Egypt is thus facing the prospect of stagnant and even declining social protection coverage (van Ginneken 2003a; Barrientos and Hulme 2009).

The informalization of Egypt's labor market has affected its younger generations in particular. With the public sector closed to most new labor market entrants, and the youth (age $15-29$ ) unemployment rate reaching 15.8\% under a standard definition and $21.5 \%$ including the discouraged unemployed (Population Council 2010: 96), the informal sector has become a common path for labor market entry. Whereas in the early I 970 s about $20 \%$ of workers started out in the informal sector, by 1998 this had risen to $69 \%$ (Moktar and Wahba 2002). Table I shows the percentage of those currently in the labor force that were enrolled in social insurance as of 2006 by age group. Among men, a consistent decline is observed from the oldest age group $(50-59)$ to the youngest $(25-29)$; among the

7 Unfortunately, reliable period data are not available from earlier years. 
latter, less than a third were covered by social insurance. Among women, social insurance enrollment declines from its peak in the $40-49$ year old age group to a low of $36.9 \%$ among those $25-29 .{ }^{8}$ It is also notable that at across age groups, social insurance coverage is significantly lower among the rural population, declining to a low of $22.8 \%$ of rural workers age $25^{-29}$.

Table 1: Percentage of current workers enrolled in social insurance, by age group, gender and residence (2006)

\begin{tabular}{|lcc|cc|c|}
\hline & Male & Female & Urban & Rural & Total \\
\hline Age Group & & & & & \\
$25-29$ & 31.8 & 36.9 & 45.1 & 22.8 & 32.7 \\
$30-39$ & 47.2 & 45.2 & 59.9 & 36.2 & 46.7 \\
$40-49$ & 61.5 & 53.5 & 73.5 & 46.5 & 59.2 \\
$50-59$ & 62.5 & 44.6 & 77.3 & 40.8 & 58.2 \\
\hline Total & $\mathbf{4 0 . 6}$ & $\mathbf{3 8 . 7}$ & $\mathbf{5 6 . 2}$ & $\mathbf{2 8 . 4}$ & $\mathbf{4 0 . 2}$ \\
\hline
\end{tabular}

Note: The age range was restricted to above 25 to avoid censoring due to education, and to below 60 because this is the mandatory retirement age for public sector workers.

Source: Authoris calculations from the 2006 Egypt Labor Market Panel Survey

These figures could indicate a life-cycle model in which workers start out in the informal sector and then move into formal employment as they gain experience. Based on research in Latin America, Maloney (I999; 2004) has suggested that the informal sector may serve as a 'training ground' for young workers. However, in the context of Egypt, existing evidence indicates that mobility out of the informal sector is low, particularly for the low-educated (Ahlburg and Amer 2003; Wahba 2009; Amer and Simmonet 2008). Among workers aged $20-50$ engaged in informal private non-agricultural wage work in 1998 , only $7.4 \%$ moved to formal private work by 2006 (Wahba 2009). There is also a strong gender dynamic to mobility out of informality; Wahba (2009) found that nearly $80 \%$ of those who successfully moved to the formal sector were male, while Amer and Simmonet (2008) find that most mobility experienced by young women in informal employment was through labor market exit. This agrees with qualitative findings that poor conditions, lack of security, and lack of benefits are barriers to women's participation in the private sector (Barsoum 2004; Barsoum et al. 2009).

8 Among the youngest age group (25-29), it is likely that social insurance coverage rates are higher among women than among men because women are more likely to remain out of the labor force if they are unable to find a high quality job, which is widely perceived to mean formal, preferably public, employment (Barsoum 2004; Population (ouncil 2010). 
The potential implications of informalization for social protection access among Egypt's younger generations are thus of considerable concern. Informal workers by definition lack contracts and social insurance, leaving them and their families without pensions in older age or in case of disability. Barring significant mobility into the formal sector or access to other forms of social protection, Egypt's young generations seem likely to suffer from little income support in retirement. Most informal workers also lack paid leaves and health insurance, making them vulnerable to health shocks. According to the ILO, such "lack of protection against catastrophic health expenditure is one of the critical factors contributing to vulnerability and poverty" (2009: 6). In short, while Egypt, like many other countries in MENA, has an extensive social protection system on the books, the combination of economic restructuring and rapid demographic growth has strained these programs (World Bank 2006), leading to growing questions about the extent to which they are accessible to those who really need them.

\section{Do the poor value social protection?}

On the other hand, some international literature has argued that workers may not value social protection to the degree that researchers and policy makers tend to expect. Van Ginneken argues that many "workers outside the formal sector are not able or willing to contribute a relatively high percentage of their incomes to finance social security benefits that do not meet their priority needs" (2003a: 66). In other words, formal social protection, which aims to provide for future consumption during periods when individuals are unable to earn an income through the labor market, may not function well to cover the immediate consumption needs of the poor. Poor households may thus see little incentive to participate in social protection, i.e. to save part of today's some income for the future, particularly for those living day-to-day (Norton et al. 2002). There is some support for such claims in Egypt; in a study of job quality among young female workers, Barsoum et al. (2009) found that some did not want social insurance primarily because this would deduct from their already low salaries. Poor understanding of how social protection systems work may also discourage participation (van Ginneken 2003a), as well as mistrust of the government that manages those schemes (Maloney 2004).

Reviewing literature on the informal sector in Latin America, Maloney (2004) has also argued that participation in formal social protection schemes may in fact have low returns under certain conditions. First, the quality and reliability of public benefits may be quite low in some countries, reducing the incentive to pay contributions in order to get these benefits. In 
the case of rural South Africa, Gouge et al. (2009) found that poor services and costs associated with accessing benefits (particularly transportation) reduced use of free health services. Burdensome bureaucratic procedures were also found to prevent some households from applying for forms of social assistance to which they were entitled.

Second, the benefits of social protection programs may be shared within the household (e.g. in cases where health insurance enrollment is extended to dependents), reducing the incentive for multiple household members to pay contributions. Furthermore, poor enforcement of labor law in many countries means that private sector establishments have significant leeway in 'choosing' the extent and level of their participation in social protection schemes (Maloney 2004). In Egypt, for example, employers commonly under-report the salaries of their employees to the social insurance administration in order to reduce contribution payments. Employees, in turn, have little incentive to oppose this practice except during the last two years prior to retirement, as this is the only period in which their pension value is based (Loewe 2004).

Finally, in a wide range of developing country contexts, social networks and transfers make up an extensive system of informal social protection on which the poor may rely more extensively than formal schemes (Morduch and Sharma 2002; Maloney 2004; Tesliuc and Lindert 2004; Goudge 2009; Davis 20II). This appears to be true in MENA, in which the World Bank (2006: 35) states that the volume of informal and non-governmental (including religious) transfers far outweighs public social assistance in all countries for which evidence exists. In Egypt, a recent study conducted in Ismailia showed that intergenerational transfers between parents and children are extensive, with female family members of both generations more likely to be transfer recipients (Yount et al. 20I2). The important role of informal community networks, and particularly rotating savings and credit associations (ROSCAs), in household saving and consumption has also been well noted in ethnographic literature (see, for example, Singerman 1995; Hoodfar 1997).

It is difficult, however, to make general statements regarding the efficacy of informal safety nets relative to formal social protection mechanisms. Many of the same scholars who have pointed to the importance of such informal transfers have also argued that they are not always reliable (van Ginneken 2003a; Loewe 2004; Goudge et al. 2009), and that their efficacy as a safety net varies considerably across social contexts and groups (Morduch and Sharma 2002). Nevertheless, informal mechanisms certainly play an important role in complementing - or substituting forformal social protection, and may well influence how poor households think about the value of such formal schemes. 


\section{Method}

The analysis in this paper in based on in-depth interviews conducted in Cairo and rural Qena, a governorate in Upper Egypt, which is the poorest (World Bank 2007) and most conservative region of Egypt. The interview sample was structured to form a comparison between two generations: older adults at or approaching retirement age $(50-65)$, who are of the generation that benefitted greatly from the expansion of public employment in the I960s and I970s, and young adults (age $20-33$ ) who have entered the labor market during the period of public sector decline. This design allows for an analysis of how labor market informalization has affected access to social protection, as well as a comparison of how the generation with much closer proximity to old age and retirement views the importance of social protection relative to the younger generation.

The study population was defined as the working poor, or what is commonly referred to as the 'popular' (sha'abi) classes in ethnographic literature on Egypt (Singerman I995; Hoodfar 1997). This population was chosen because it is the socioeconomic class for whom the amounts of income typically distributed through social protection programs in Egypt - anywhere from I2 to I2O USD per month ${ }^{9}$ - may have a significant impact on household spending power. Given the lack of qualitative literature focused on social protection, an exploratory design was adopted in order to reach a range of respondents with different forms of access to social protection mechanisms. Interviewees were chosen based on a purposeful sampling technique, in which a set number of individuals who fit predetermined categories based on age, sex, labor force participation, and access to social insurance or social assistance were interviewed. Education level was not used as an additional sampling criterion because the criteria used already lead to a wide distribution in respondent characteristics within a fairly small sample. It is worth noting that due to this, the sample may be biased toward the more educated, because many of the labor force categories sampled (particularly those with social insurance) tend to be dominated by the more educated.

Fourteen interviews were conducted with young adults (seven female, seven male), and $\mathrm{I} 3$ with older adults (seven female, six male) in Cairo.

9 It is important to highlight here that the aim of this paper, as with most qualitative research, is not to make generalizable statements about social protection access at the population level, and it is therefore not necessary to have a large representative sample. Rather, the aim of this qualitative analysis is to illustrate the hows and whys of individual values and decision-making issues that are often difficult to address with quantitative data. Hence, in illustrating the challenges faced by some individuals and households in terms of accessing social protection, this study does not make the claim that these are problems common to the majority of Egyptian households, but points to issues that are worthy of further study for both academic and policy purposes. 
Thirteen interviews with young adults (seven female, six male) and I 3 with older adults (seven female, six male) were conducted in rural Qena, for a total of 53 interviews. The distribution of the sample by location, generation, gender, and access to social protection is shown in Table 2. It is worth noting that considerable difficulty was met in identifying respondents of this socioeconomic background who were employed in the private sector with social protection (i.e. social insurance enrollment) among all groups except male youth in Cairo. For this reason, self-employed individuals who had enrolled themselves in social insurance were interviewed in place of protected private sector employees in the older adult and rural categories, and only one young woman in Cairo and one in Qena with protected private sector jobs were located for an interview. Respondents in Cairo were identified through a snowball sample starting from an interviewer who lived in a sha'abi neighborhood, and respondents from Qena were identified through the networks of a local NGO.

Table 2: Distribution of the qualitative sample, by location, gender, generation and social protection status

\begin{tabular}{|c|c|c|c|c|}
\hline \multirow[b]{2}{*}{ Younger Generation } & \multicolumn{2}{|c|}{ Cairo } & \multicolumn{2}{|c|}{ Qena } \\
\hline & Female & Male & Female & Male \\
\hline Public sector employee, social protection & 1 & 1 & 2 & 2 \\
\hline Public sector employee, no social protection & 1 & 0 & 2 & 0 \\
\hline $\begin{array}{l}\text { Private sector employee or self-employed, with } \\
\text { social protection }\end{array}$ & 1 & 2 & 1 & 1 \\
\hline $\begin{array}{l}\text { Private sector employee or self-employed, no } \\
\text { social protection }\end{array}$ & 1 & 3 & 0 & 2 \\
\hline Unemployed or out of labor force $\S^{\S}$ & 3 & 1 & 2 & 1 \\
\hline \multicolumn{5}{|l|}{ Older Generation } \\
\hline Public sector employee, social protection*\$ & 3 & 2 & 2 & 2 \\
\hline $\begin{array}{l}\text { Private sector employee or self-employed, no } \\
\text { social protection }\end{array}$ & 1 & 3 & 0 & 2 \\
\hline Self-employed, with social protection & 0 & 1 & 1 & 2 \\
\hline Out of labor force ${ }^{\S}$ & 2 & NA & 2 & NA \\
\hline Recipient of social assistance pension** & 1 & NA & 2 & NA \\
\hline
\end{tabular}

Notes: * Either currently employed in the public sector or receiving a contributory pension.

**Due to the difficulty of locating the small population of men receiving a non-contributory pension, this group was excluded from the sample.

$\S$ At least one of the female respondents in this category was receiving survivorship benefits at the time of the interview. 
Interviews covered the interviewee's current and past employment conditions, including social insurance coverage and other employmentrelated benefits such as health insurance. They also covered household access to pensions and other forms of social protection, expectations regarding retirement and old age support, generational comparisons regarding access to social protection for today's youth versus their parents' generation, and a discussion of how important the extension and reform of social protection programs should be for the post-January $25^{\text {th }}$ revolution government. Additional questions on the choice of whether or not to work were included for women. The bulk of the fieldwork was conducted in June and July 20II, with some additional interviews conducted in November 20II. All translations are the author's. ${ }^{10}$

\section{Results}

This section presents the results of the interviews according to the four generation/gender categories included in the study. For each group, broad common life trajectories in relation to the labor market and access to social protection mechanisms are discussed. The primary aim of the analysis was to identify key vulnerabilities faced by each generation/gender group, and the extent of their access to social protection mechanisms that could alleviate those vulnerabilities. Perceptions of the value of different forms of social protection are also addressed. The discussion focuses on social insurance, health insurance and non-contributory pensions (commonly known as Sadat and Mubarak pensions), as these are the three most widespread forms of social protection in Egypt, and were the mostly commonly accessed forms among the study population. ${ }^{\text {II }}$

10 Quotes have been lightly edited for readability.

11 Interview respondents were also asked about unemployment benefits, maternity leave (for women), and aid from charities, religious organizations or other civil society. As noted above, there is a legal provision for unemployment benefits for certain categories of Egyptian workers. However, the requirements are quite restrictive (SSA 2011), and actual receipt of these benefits seems to be extremely rare. Those of the respondents who had heard of the concept associated it with political calls post-January $25^{\text {th }}$ to provide aid to Egypt's unemployed youth. Many were adamant that at the current time such a thing existed only outside Egypt. Outside the public sector, maternity leave is rare, and only one female respondent in the younger generation had benefitted from it. None of the respondents said that they or any members of their household were currently benefitting from non-public forms of social assistance. 


\subsection{Older men}

The group of older men was split between two main life trajectories: public sector employment, and employment, or self-employment, in the informal economy. Among residents of Qena, the latter included agricultural work. Educational levels for those in the informal sector ranged from two-year technical post-secondary degrees to illiterate, whereas three of the four public sector employees had at least a secondary degree and one was an illiterate factory worker in Qena.

Government employment provided clear advantages to the men of this generation in terms of stability and security, as well as access to social protection. They were "appointed" in the government sector shortly after finishing their education, and had remained in their jobs ever since. All had social insurance and health insurance. These and other benefits of government employment were widely acknowledged, and educated respondents in particular lamented the difficulty faced by their children's generation in finding such jobs now that the public employment guarantees were no longer in effect. The public sector was a less vivid comparison point for the less educated, for whom opportunities in this sector have always been lower, yet several also noted its advantages. All but one agreed that employment opportunities for men had declined since they were young.

Among the group that had not benefitted from public sector employment, access to social protection through contributory social insurance pensions was mixed, and none had health insurance. In the rural study site, where the private sector is under-developed and education levels among the older generation were low, the thought of enrolling in social insurance had clearly never occurred to several of the respondents, who neither understood the process nor had the income to pay the contributions. The self-employed, "independent" workers who registered themselves with social insurance did so because they were told to when they went to get licenses for their work. They too had little understanding of the system, and were unsure at what level they were considered to be contributing, although they knew their monthly payment. ${ }^{12}$ They were also unsure of what their eventual pension value would be, but did not expect much. Irregularity of contributions was also a problem among this group, whose incomes varied from month-to-month, particularly given their advanced age. At the time of the interview, a self-employer tile layer in Qena, age 6r, said he was unable to work due to health conditions and

12 Most of the self-employed interviewed through this project were making social insurance contributions at the lowest possible self-declared income category, with a monthly contribution of 7.5LE (approximately $\$ 1.25$ at current exchange rates). 
said he had not paid his social insurance contributions for over a year. He would be financially reliant on his son until he reached the self-employed retirement age of 65, at which point he planned to rely on his pension. However, he seemed unaware that his failure to make his contributions during the intervening period could affect his pension eligibility.

Labor force discontinuity was also a problem in terms of social protection access among the Cairo sample of informal sector workers; all three of those who were uninsured at the time of the interview had, at some point, been enrolled in the social insurance system but had not met the minimum 120 months of contributions to be eligible for a pension. Individuals are allowed to make up for any shortage in number of contributions by "buying" those contributions from social insurance,$^{13}$ but these older workers faced challenges in coming up with such sums. Said one man, age 53, who had left a job with social insurance and then tried to reinvest in the system:

I thought about completing the insurance the way it was, but I found they were telling me I don't know how many percent for the period that I wasn't paying [my contributions], so of course it's not possible for me to go pay about six years [worth], pay all that time that passed, with a fine as well.

Another man, age 56, became self-employed after working at a barber shop for years where he was covered by social insurance. However, with his reduced income as an independent worker he was unable to cover both his contribution and what would have been his employer's. Contributing to social insurance also became a low priority. As he said "all my attention is on feeding the kids."

Although many of the men of this generation did not have access to pensions, the abstract value of social insurance was recognized by all; when asked whether they thought it was better to put a portion of their salary into personal savings, a private pension fund or the public pension system, all respondents said public pensions were the best option. Private insurance is not well known in Egypt, and all said that it was not realistic to expect that they would save money to provide for a retirement given the financial pressures of supporting their households today. The disability and survivor benefits provided to families by the public pension system were also an important consideration for the more educated urban population. Thus, the low level of understanding of social insurance did not seem to translate into mistrust of the public system among this generation.

13 Interview with a representative of the Social Insurance Administration, 25 June 2012. 
One consistently noted problem with pensions, however, was their low value, which was widely said not to cover a household's expenses. None of those who were receiving or expected to receive a pension planned to live on that income alone. As with those rural residents who did not have a pension, several of the older men in Qena were relying or expected to rely on their sons to make up for any household needs not covered by the pension. In this context, where extended family and multi-generational households are common and some households have agricultural land, such informal forms of social protection in old age were more prominent than in the urban study site. In Cairo, along with some of the other men in Qena, this generation planned to secure their old age through selfemployment or informal employment. The idea of starting a small business or "project" in older age was common, and those who were already selfemployed planned to continue working if they were able. Others were already working in second jobs to supplement their pensions, or had jobs lined up for when they retired. ${ }^{14}$ By definition, these jobs had to be in the informal sector as it is not possible for those taking a pension to register for social insurance coverage. For those with pensions, informal sector employment thus served as a complement, rather than a supplement, to social protection access. However, compared to those with no social protection, pensioned retirees acknowledged that they had an important degree of security. Said one retiree, 6o, who had a car that he rented out as a form of income generation, on preferring the pension system over other forms of retirement support:

Even though it's not enough, you know it's guaranteed, there's something there at the end of the month, better than nothing. With independent work in Egypt, you can come to the end of the month and there's nothing at all...or you could have to stay home, you get sick, or anything happens and you have nothing...there's a big difference of course.

\subsection{Older women}

Older women also tended to follow one of two main life trajectories: public sector employment, or life as a housewife. However, as is common in Egypt, several of those who had spent most of their lives as housewives had also spent intermittent periods of time engaged in wage work or incomegenerating activities, particularly in the rural study site. Most of these had engaged in petty trading, but one woman in Qena was currently working in her family business, a mill, and one woman in Cairo was working in a secretarial job. Both had re-entered the labor market within the last several years before the interview, once their children were at least in preparatory

14 Egypt's public sector has a mandatory retirement age of 60. 
school. As expected, family reasons - including household responsibilities, childbearing and husband's opposition - were the main reason for labor force discontinuity among the older women, whereas labor market factors were the main source of discontinuity among older men. Among this generation of women, as with the older men, the only individuals who had had steady employment since their youth were the public sector employees. All of these older, female public sector employees had at least a secondary degree. In Cairo, the educational level of housewives and those engaged in the informal economy ranged from illiterate to post-secondary vocational degrees. Among the housewives in Qena, none had completed primary school and the majority could not read or write.

As with the older men, women of this generation engaged in public sector employment enjoyed a considerable degree of stability and privileged access to social protection relative to those who had never or inconsistently been in the labor market. They benefitted from the public sector's generous maternity benefits, and although not all could afford to take the longer unpaid leave for childrearing, the three government employees who had children had all taken at least one three-month leave. The fourth woman had been able to take early retirement at age 45 in order to care for her ailing husband. In addition to the other social protection benefits that all public sector employees enjoyed, the fact that the requirements of their family roles did not cause them to lose pension benefits was certainly a considerable advantage of public employment among this group. As with older men, the security of the public sector was highly valued by these women, and they too saw the decline of public sector hiring as a major social ill. Again, among the less educated population, particularly in Qena, the sense of decline over time was less linked to employment opportunities.

Another major benefit of the expansion of public employment for this population of older women, regardless of their employment status, was the survivor benefits they inherited from husbands who had worked in the public sector. Although eligibility for survivor benefits was not among the sampling criteria, it was found that all of the older women in Cairo who were not receiving social assistance, and four of the five in Qena, were currently receiving or could expect to receive survivor benefits from their husband's public sector pensions. For those who were themselves public sector employees, these survivor benefits served (or were expected to serve) as supplements to their own pensions. However, for those who were housewives or working in the informal sector, these survivors pensions were, or would be in the case of widowhood, their primary source of income. Although many of the women in this generation, and particularly those who were not public sector employees, also had a low understanding 
of the social insurance system, the fact that pensions were inheritable by surviving widows and children was quite widely known.

Survivor benefits were such an important source of income support for the older female respondents because, unlike the men of their generation, they felt they had few options for income generation in their old age. A combination of advanced age, health concerns, and social constraints played into this. The women without education largely saw that they did not have, and in fact had never really had, options for work in the wage market. This was compounded in some cases by family and community resistance to the idea of women's work. In both study locations, even for those who were public sector employees, the idea of starting a "project," as the men planned, was not an option they considered. Some women could expect to receive additional support from their grown children (primarily sons), although others still had dependent children who they were supporting from inherited pensions. Thus, as one 6r-year old explained, "you live at the level of the money...you don't spend beyond your means."

This is not to say that this group of older women was satisfied with pension levels, whether those were contributory, non-contributory, or survivor benefits. Particularly for those receiving only survivor benefits or non-contributory pensions it was clear that the amounts were not sufficient to keep the household out of poverty. Perhaps for this reason, inflation and the rising cost of living figured most prominently in most women's comparisons of their youth and the current time. The perception that it had become much more difficult to provide for a family even on nominally larger sums of money was a much more vivid aspect of the perceived generational decline among this group than labor market factors.

Although there is no doubt that informal transfers alleviated the situation of some of the female-headed households, several cases illustrated the argument that those in most need may have limited networks in terms of reaching better-off individuals able to give. For example, the Cairene woman, age 62, who was receiving a non-contributory pension received I39LE (approximately \$23) per month. ${ }^{15}$ She received occasional gifts of foodstuffs from neighbors as well as money from her sons, two of whom were self-employed carpenters and one of whom was a casual laborer (none registered with social insurance). But at the same time, she sometimes gave money to a daughter who had three children and whose husband was not always able to provide for the family's needs. Thus, while there was a flow of goods and money within the extended family and sometimes from others, none were in a strong enough economic position to pull

15 This respondent was the only one of the three receiving a non-contributory pension who started receiving the pension while married. The other two women from Qena both started receiving the pension after they were divorced. 
the respondent - or the family - out of poverty. It was also a common perception among the respondents that non-contributory pensions were only for divorcees and widows with no family support, and there was a certain stigma attached to not being provided for fully by family networks, particularly among the Cairo residents.

Still, despite the low amounts, the women of this generation valued the public pension system highly and, like the men, saw it as superior to any form of private saving for old age because it was something guaranteed. The same could not be said of the health insurance system, which had low value in the respondents' eyes due to of the poor quality of service at the public facilities to which patients must go in order for the health insurance to cover their treatment: ${ }^{16}$

Unfortunately, the illness I had, health insurance won't cover the right treatment for it, because the health insurance covers a certain amount and the treatment was more than that amount, so they would give me something that wasn't appropriate...so I went and bought it [the medicine] from outside - Public sector retiree (early retirement), age 58 , Cairo Health insurance is important but it's not good here in my village, I for example, I would go to the health insurance [clinic] and every time they would say you'll take an alternate [treatment], there isn't this, there isn't this - Public sector retiree, age 64, 2ena

For this reason, most of those who had health insurance, either through employment or survivor benefits, did not use it. Notably, some of these same women said that their pension was not sufficient to cover their living costs specifically because of the health expenses they incurred going to other facilities. Unlike the respondent quoted above, the poor quality of the health insurance system even led some older women to discount the importance of having health insurance to begin with, as illustrated by this exchange with a 50-year-old housewife receiving survivor benefits:

I: Did you get health insurance with the pension?

$\mathrm{R}$ : I refused to enroll, I refused, even though I'm sick, I go to $[$ another hospital $] ..$. my brother gets me the medicine, I just went and did an ear exam, he was the one who got me the

16 The older male respondents also noted the poor quality of the health insurance, and also noted that they did not use their insurance, but the issue figured less prominently than in discussions with women. Access to health insurance was also less common among the older males, since many of the older women had health insurance through their survivor benefits. 
medicine....health insurance isn't good.....because they take a lot of money, from the one [female] who has a pension, they take a lot of money from her pension....they take 40LE per month whether she gets any treatment or not

I: So you don't want health insurance at all?

R: No, I go outside [the health insurance system], I don't want it, I go elsewhere

The public health insurance system was thus doing little to reduce vulnerability to large health care expenditures among this older population, who resorted to spending part of their already limited pensions on health care, or relying on family transfers to cover health expenses.

\subsection{Male youth}

For male youth in both study locations, the stable life path of longterm public sector employment followed by the older generation (who were of their fathers' generation) was more of an ideal than a reality. This generation was significantly more educated than the older men; only one youth in Qena had less than a secondary education, and all of those in Cairo had at least a two-year post-secondary degree. ${ }^{17}$ Nearly all would have qualified for government jobs during their fathers' time. Yet with the system of government hiring effectively closed, their employment experiences were more varied than the older generation's and much less strictly divided between public and informal employment. All of these male youth said that opportunities for finding good quality jobs had declined significantly since their fathers' time and were extremely limited for their generation. Facing the pressure of supporting young families or trying to save for marriage, salary and job security dominated this group's thinking about quality employment, with social protection often a fairly distant consideration.

The public sector was still something of a labor market option for these young men, but had lost some of its key benefits, including that of easy access to all graduates. In Qena, where all of the young men interviewed saw the public sector as the best form of employment, such positions were said to be very difficult to get, requiring connections or substantial bribes

17 Educational attainment in Egypt has risen considerably over the course of these two generations. Whereas about 55\% of men born between 1953 - 1962 (the older generation in this study) obtained less than a secondary education, among the 1983 - 1988 birth cohorts (near the ages of the younger generation in this study) this declined to $38 \%$. Among women of the same generations, the corresponding figures are about $72 \%$ and $41 \%$, respectively (Sieverding 2011). Nevertheless, the sample of youth in this study may be biased toward the more educated due to the sampling criteria, as noted in the methods discussion. 
to secure. Both of the two young men working in the public sector in this location got their jobs through the preferential hiring system for children of current government employees (abna a'mileen). Even then, one had been hired on a temporary contract and was only given a permanent position after the January $25^{\text {th }}$ revolution during the brief wave of government efforts to give youth better access to the public sector. The young man in Cairo working for a public sector agency was similarly on a temporary contract and did not know whether he would be upgraded to a permanent position. For other male youth in Cairo, the advantages of government employment had declined to the point that several had left contract-based public sector jobs for the informal private sector. The key factor in this decision was the higher salary they were offered in the informal job.

In Qena, those youth who had not secured public sector employment had either given up on or never really considered the idea of social insurance; as far as they were concerned, the formal private sector was non-existent. One said that he was not even aware you could get social insurance if you were not a government employee. The one young man who had social insurance through a means other than government employment was a 29-year-old shop owner who had insured himself and the shop. When asked why, he explained that he did not really understand the system, but one of the village elders had told him that this was the best thing for him to do, and had completed the paperwork for him and told him which contribution level was best.

In Cairo, in contrast, most of the young men interviewed had had at least one job where they were covered by social insurance. However, discontinuity of employment, even more so than among the older male informal workers, was a major factor among this group. Most had worked multiple jobs since finishing their education, punctuated by periods of unemployment, in a continual search for a job that was better paid, more suited to their qualifications, and in which they were better treated. Youth were also willing to leave their current employment as soon as they found something better. As a result of this turnover, they did not necessarily think that they would benefit from the periods of employment during which they had contributed to the social insurance system. Even if one employer insured them, the next may well not, leading youth to expect that any social insurance contributions they did make would effectively be money lost.

This instability of employment, including highly personalized relationships between employee and employer, dominated the Cairo youth's perceptions of the private sector. Their feelings of insecurity also affected their bargaining position vis a vis their employers in terms of gaining access to social insurance through their work, and few seemed 
willing to bring up the subject. One 30 -year-old, who described six previous positions in the nine years since he had graduated with his B.A., described the situation in his current job in a restaurant:

I: Your employer doesn't insure anyone at the restaurant?

$\mathrm{R}$ : Recently some people went and caused a problem with him, so the social insurance [inspector] came and filed a report and that kind of thing, so it looks like he'll take two or three [employees] and insure them.

I: Not everyone? You didn't negotiate with [the owner] to insure you?

R: I...in terms of him [the owner]...the negative effects of the revolution are there, that the cafes and restaurants are just getting by...here the way it goes, they say 'hey, there's a revolution, I'm going to get rid of that guy I don't like, there's a revolution, let's lower salaries'....

Under this situation, with his salary already reduced to about half, the young man was not willing to join his colleagues in their negotiation for social insurance.

Another 33-year-old teacher worked for a private school that reported less than a quarter of his salary to social insurance. Although this young man was under the impression that he was paying both his share of the insurance contribution and his employer's, or $40 \%$ of his reported salary, ${ }^{18}$ he had not brought the issue up with the employer:

I: So there weren't any negotiations between you and your employer or the school administration, that they would increase your insurance [reported salary]?

$\mathrm{R}$ : Not at all! When the social insurance [inspector] comes it's like an exam, there's this fright from the inspector, and they go around to some of the employees and choose some of them - and I've been one of them a couple of times: "You'll be asked, are you insured? Yes, I'm insured"

I: They [the inspectors] don't ask how much [of the salary] is insured?

R: No, no. Most of the time the inspector from the social insurance just goes to the school administration and everything is done [i.e. he is paid off].....

18 It was not possible to verify this employee's claim that his employer was deducting the entire $40 \%$ from his salary, but a quick calculation of his approximate contribution and reported salary suggested that this was not in fact the case. 
Although he would have liked to have a larger portion of his salary reported, since it was a good salary the teacher was not willing to leave the job over this issue. Several of the young men interviewed, as well as some of the older adults in Cairo, also said that it was common practice in the private sector to have employees sign an undated official resignation (known as istima'ara sita or "Form 6") at the same time that they signed work contracts and were registered with social insurance. In this manner, the employer effectively bypassed labor law clauses protecting employees from arbitrary dismissal at the same time that he formally registered the employee.

For most of the youth, such concerns with job security and wages outweighed the issue of social protection. Yet when asked whether public social insurance, private pension funds, or personal savings were the best way to save for retirement, young men in both study locations, like the older generation, overwhelmingly said that public social insurance was the best option. They saw saving on their low salaries as nearly impossible, and mistrusted the idea of private pension funds, much like they mistrusted private sector employers. Said one youth in Qena, "I prefer the government, if it's a private group the one responsible for the insurance may take the money and run. But with the government, the money is there." Young men also said that government pensions would provide for their families in case of their death.

Nevertheless, the desire for social insurance conflicted with the realities of the labor market and more immediate income needs, as illustrated by one 26-year-old worker in a print shop in Cairo:

He [my employer] wanted to insure me, but I refused because it will deduct $\mathrm{I} 4 \%$ from my salary. My base salary is IoooLE, so if he deducts $14 \%$ it will be I4OLE, and those I4OLE will make a difference for me - I am a man getting ready for marriage and those $\mathrm{I} 4 \mathrm{OLE}$, if I went into a gameiya [ROSCA] with them they'll make something...so it's not the time for it [i.e. insurance]

When the same young man, later in the interview, said that social insurance was one of the benefits he would like to receive through his job, he explained the apparent contradiction in his refusal, "it's not that I don't want it [social insurance], of course I want something like that, but I won't take from my salary and affect my [current] situation for insurance that I won't take, or that I won't see its benefit except in the far future." 
In light of the reality that many were not insured - and also well aware of the fact that pension values are low-most of these young men expected to follow the model of the older generation and support themselves in old age through continued informal employment or self-employment. Yet their ideas of future support were vague, conditioned by uncertainty and low standards of living. Under the difficult economic conditions these young men faced, this uncertainty also surrounded their ideas of how their parents would be supported in their old age, as illustrated by this extended dialogue with a 29-year-old, married government employee in Qena:

I: Your father, will your father's pension be enough [to support the housebold]?

R: I don't know....his income will be average, they'll take away the bonuses and allowances [when he retires]

I: How will they [your parents] provide for themselves?

R: God will provide for them, God willing.

I: Is it expected that you'll help him?

R: No, that was before. Now everyone goes along [spends] according to his situation.

I: You yourself, when you retire, how will you spend on your family?

$\mathrm{R}$ : The same thing, from the pension.

I: Do you expect the pension will be enough?

R: No...I could do a project, later, from the pension that I'll take, from the end-of-service reward...I don't really think of these things, I think day-by-day.

I: Why do you think day-by-day? Why don't you plan ahead?

R: Like I told you, I spend everything I make, in this situation, with all my expenses....

I: Do you feel secure, because you have a [government] job?

R: No I don't feel secure, and the salary, it's just barely enough.

Several of the young men in Qena and Cairo were already in fact helping to provide for parents who were living with them in multi-generational households, although expectations for parental support were less prominent among the Cairo group, most of whose parents had access to a pension. Other young men felt they would be financially unable to provide much support to their parents; one young man in Qena acknowledged that while he should help his parents, his income was so stretched providing for his own children that he was not sure whether he would be able to do so. The restaurant employee in Cairo quoted above said that his parents were more often the ones helping to support him. Thus, while 
there were certainly intergenerational transfers flowing both to and from this generation of young men, their overall feeling of economic insecurity contributed to considerable uncertainty over how either they or their parents would provide for their old age.

\subsection{Female youth}

For female youth, the stable path of government employment that women of the older generation (who were again also of their mothers' generation) had followed was as distant a possibility as it was for the male youth. Whereas the older generation of women was divided largely between public sector employees and housewives, the younger women, like the younger men, therefore had more variable labor force experiences. Though generally split between those who worked in the informal sector and those who withdrew from the labor force, even this boundary was more blurred, as many of those out of the labor force were willing to work if they found jobs that met certain conditions. Like the male youth, this group of young women was considerably more educated than the older generation, with only one woman in Qena not having completed secondary school, and all of those in Cairo with at least a two-year post-secondary degree. Unlike the other groups in the study, education conditioned these young women's views on change in labor force opportunities for women. All of the young women in Cairo said that work opportunities had been better for their mother's generation, and those in Qena agreed as far as educated women were concerned. But, since many of their mothers had not been educated, they thought that they personally had better opportunities for work due to their educational credentials and greater social acceptance of women's work in their villages. Nevertheless, the difficult conditions of the private sector labor market made all of these young women's longterm prospects for work quite uncertain.

As expected, concerns over treatment at work from supervisors and colleagues, the appropriateness of the job for women, working hours, and distance from home dominated these young women's ideas of what constituted quality employment. Salary also figured into their considerations, particularly among those in Cairo, several of whom felt that usual salary levels for the types of job available to them were simply not enough to make working worthwhile. However, benefits such as social and health insurance were rarely mentioned in young women's descriptions of important working conditions. When asked why not, one 29-year-old woman in Cairo responded "I guess because I work in the private sector and I got used to the fact that these things aren't available." Similarly, a 25-year-old teacher in Qena responded, "it's not that these things are not important but it is just fairytale talk!” 
In fact, for the young working women, social insurance, health insurance, maternity leave, and paid vacation or sick days were not always available even in the public sector. The teacher in Qena, for example, worked on a temporary basis in a public preparatory school for 199LE (approximately \$33) per month. She described her work conditions:

We get fired [contract severed] for four months every year, so that they don't have to pay us for the time when school is out, and also so that we don't continue for five years with this scheme so they donst have to hire us [with a contract]. Then they rehire us when school year begins. They deduct 2-3 LE for every day that I miss work. We are not even entitled to vacations, no insurance, and no pension.

Another young woman in Qena worked in a nursery affiliated with a public school on a class-by-class basis, receiving a wage of $2 \mathrm{LE}$ per class, and one young woman in Cairo had an administrative job at a university where she was also paid by the day. At the time of the interview, she was unemployed during the summer vacation, waiting to see if she would be re-hired during the coming academic year. As with the male youth, these female youth said that obtaining a government job with a contract and benefits required connections (wasta) or a parent in the public sector who could get them hired through the children of employees scheme.

Although most of the young women who had ever worked in the private sector had simply given up on - or never in fact thought about - the idea of employment benefits, the experiences of those who were enrolled in social insurance, or had the option to be enrolled, revealed a deep mistrust of private sector employers compounded by a poor understanding of how the social insurance system works. One 25 -year-old woman in Qena, currently unemployed, had previously worked in a nursery. She said she had had the option to enroll in social insurance, but didn't understand the system and wasn't willing to part with the money for the contribution, which she thought were just deductions that she would not see again. Another 27-yearold's experience with her employer in Qena demonstrated both private sector evasion of social insurance laws and young women's suspicion that they will never benefit from the contributions being deducted from them:

The insurance should be $40 \%$ of the salary, and according to the law, the employee bears $14 \%$ of the cost and the employer $26 \%$. So there was a problem, the organization didn't have the money to pay the $26 \%$ of the reported salary, so they said they'll take from us the whole amount. So what would make 
me pay half of my salary, a little bit less, for insurance? Which I may or may not take in the end [as a pension]?

The organization eventually agreed to pay its part of the contribution, on a reported salary of $200 \mathrm{LE}$ per month, whereas the employee was actually making $750 \mathrm{LE}$ per month. She said she was not happy with this situation because this level of contribution would yield a very small pension, but at the same time would have preferred not to enroll in social insurance at all. She explained:

I: So, you told me you were forced to enroll in social insurance? $\mathrm{R}$ : Yes, because the organization made me.

I: But now you're saying you want them to report your whole salary?

$\mathrm{R}$ : Yes, if I'm going to have insurance, then it should be something good, something that we'll take a pension at the end. But why bother for such a small value?

Unlike this young woman and her colleagues, most young women were hesitant to negotiate or even open the topic of benefits with their employers. One 29-year-old in Cairo was also insured at a lower salary than she actually received, although she did not know at exactly how much, and was also under the impression that all $40 \%$ of the contribution was being deducted from her salary. ${ }^{19}$ She said she wished she had had health insurance to cover a recent pregnancy, but had never discussed the issue with her employer, a tourist company. As, she said, "you just sign [the contract] because there is no work.... I haven't tried to do anything about the insurance, they just say 'bring your papers for the social insurance."

Surprisingly, knowledge of social insurance was low even among those young women who had public sector benefits. None of the three young women with government contracts knew whether or not they were enrolled in social insurance. One young woman in Qena, age 22, who was a permanent public sector employee and therefore by definition had full benefits, explained why she didn't find the idea of social insurance important and did not think she was enrolled:

First of all, because we don't understand it. We haven't seen what social insurance is really, so because of this I even don't participate, because I don't know what social insurance is. Except for the term - I hear the term social insurance but I

19 Again, this could not be verified, but a rough calculation suggested that it was not the case. 
don't know what it means. And I haven't benefitted from it, I mean, if I have social insurance, me and my family, what will that look like? So I don't care if I have it or not because I don't understand it.

She had never asked about her benefits, and did not know that contributions for these benefits were being deducted from her salary, because she had never checked her employment conditions. Another young woman in Cairo, age 33 and working in the government on a temporary contract, said that deductions were made from her salary but she was not sure if she would get a pension:

I: Do they deduct social insurance from your salary?

R: Yes, they always deduct things.

I: Do you know how much they deduct?

R: No, I don't know, I don't have any information on what they deduct or not, they told us that we get a pension but there are people who say that those on contracts don't get a pension after they finish, that that's the difference between us and those who have permanent jobs, the pension.

I: You didn't ask?

R: No, I didn't ask. But they [colleagues] say that I'll get a pension, I asked them once when a big deduction was taken from my salary, and they said it's a deduction for the pension. I'm not sure if that information was right or not.

Awareness of social insurance and other forms of social protection was similarly low among those not working. Most of the young women, whether employed or not, saw health insurance and maternity leave as more important than social insurance in the abstract, as these forms of social protection addressed their and their children's immediate needs. However, very few had ever had access to such benefits. ${ }^{20}$ Some young women also saw less reason to contribute to social insurance because they did not expect to be employed for long periods due to family demands, and consequently expected to lose any contributions paid. Egyptian law

20 Among the younger women interviewed, only one, the 29-year-old employed in a private tourism company, had ever taken maternity leave. Her company granted her the legal three months with full pay, and she said that she took the first two without difficulty. However, the January $25^{\text {th }}$ revolution then occurred, and when she went to pick up the check for the third month she was given only half her salary, with the justification that the revolution had caused financial problems for the company. She was then placed on five months of unpaid leave without her consent, and at the time of the interview was still waiting to see whether she could return to her job. 
provides a provision for women who withdraw from the labor force due to marriage to withdraw their social insurance contributions, but young women were unaware of this. ${ }^{2 \mathrm{I}}$

Aside from general lack of knowledge, part of what contributed to young women's lack of concern with social protection was the norm of male providership, which was particularly strong in Qena. This applied both in terms of the expectation that their brothers would bear primary responsibility for supporting aging parents if needed, and in the expectation that their husbands would be financially responsible for providing for their own households through retirement. To the extent that they could answer questions about how they would provide for themselves in the event of widowhood, most expected to rely on survivor benefits. In the face of the reality that many (potential) husbands today are not contributing to social insurance, they had little to say. As one young woman, age 26 and working in the informal sector, responded "I won't have a pension, there isn't any stability for me. I'll live from my husband's work or my husband's pension, and if he doesn't have, honestly I don't know. There isn't anything. There won't be any security."

\section{Discussion}

This paper presents a comparative analysis of how four age/gender groups perceive of and access social protection in Egypt: older men and women age $50-65$, and male and female youth aged $20-33$. Though different issues in terms of access to social insurance, health insurance and non-contributory pensions were more prominent in discussions with each of the different groups, several common vulnerabilities emerged across generations and genders. These included labor force discontinuity among workers in the private sector, women's dependence on survivor benefits, low pension values, and poor quality of and limited access to health insurance. Finally, lack of awareness of social protection mechanisms and poor understanding of how they function served as an important barrier to access among all groups. In this section, these sources of vulnerability are discussed and policy recommendations for addressing them are put forward.

21 Interview with a representative from the Social Insurance Agency, 25 June 2012. There are also stricter conditions for men to withdraw their social insurance contributions, including reaching retirement age without having made enough contributions, imprisonment, and emigration. Again, this was not something respondents in this study seemed aware of. 


\section{Labor force discontinuity}

Those workers who were unable to secure permanent government or formal private sector jobs often experienced a considerable amount of job turnover in the informal sector. This was particularly true among young men. This group was still early on in their careers and had the chance, at least among those in Cairo, to eventually find a stable formal job and become eligible for a contributory pension. Yet until they felt they were in such a secure, life-long job, youth were ambivalent about formalization. Social insurance was a low priority in the difficult search for a good job, and unless they expected to stay in one place long-term, they did not necessarily see the sense in making social insurance contributions that might not yield a pension. Although quite rational in the immediate term, this meant that some were giving up the opportunity to make contributions that might in fact have helped them accumulate the 120 months of contributions needed for pension eligibility.

Part of what this suggests is that workers need better education on the eligibility requirements for receiving a contributory pension, including the I2O month requirement and how periods of missed payments are dealt with. These issues of awareness will be discussed more below. However, broader reforms are also needed to encourage social insurance participation among informal workers and eliminate penalties for discontinuous enrollment in social insurance. A reform of the social insurance law (Law 135 of 20IO) was in fact passed by the Egyptian parliament in 20I0. This law included a reduction in the employee contribution level to $1 \mathrm{i} \%$ and eliminated a cap on pensionable salary, effectively lowering contribution levels for lowearning workers and raising them for high-earning ones. Importantly, the law also included a minimum pension clause, which will make all citizens age 65 or older with no other form of support eligible for a pension equal to ${ }_{15} \%$ of the national average wage..$^{22}$ This could provide an important safety net for older workers in the informal sector for whom it is already too late to become vested in the social insurance system. However, although Law 135 was scheduled to come into effect in January 2012, its status is currently unclear due to the aftermath of the January $25^{\text {th }}$, 2 II revolution. Addressing the status of this law and other reforms to the social insurance system should thus be on the agenda of the new government.

22 For more information on Law 135, please see: http://www.socialsecurity.gov/policy/docs/progdesc/intl_ update/2010-07/index.html\#egypt and the ISSA's Social Security Observer 13: http://news.issa.int/layout/ set/print/newsletter/newsletter_repository/observer/en/social_security_observer_13\#5729 


\section{Women's dependence on survivor benefits}

Due to the low labor force participation rate, particularly in the formal sector, of Egyptian women, their individual access to contributory pensions is fairly low. Yet for the older women in this study, the provision for survivor benefits for widows meant that the expansion of public sector employment provided many with social protection through employed male relatives. The younger generation of women, who had even less personal access to formal public sector employment than the older generation, also expected to depend on such benefits if their husband was not alive to provide for the household. However, given the high level of informality among the generation of young men, barring significant formalization, these women may be left with no formal income support in case of widowhood.

In order to provide social protection to women directly, rather than relying on the increasingly tenuous prospect of survivor benefits, efforts should be made to expand the reach of social assistance. The full implementation of the minimum pension clause in Law 135 could be an important step toward reducing vulnerability among older widows who do not have access to survivor benefits. However, additional expansions to the social assistance system are also important to reach women under age 65 in vulnerable households. Currently, non-contributory pensions are not widely received in Egypt, and were found to be somewhat stigmatized among the study population, particularly in Cairo, due to the perception that they are primarily for divorcees, or other women with no male provider (for more on gender, stigma and targeting, see Sabates-Wheeler and Kabeer 2003). While social assistance should certainly continue to cover younger widows and divorcees of all ages, expanding its effective reach at least to other groups of non-elderly women might help de-stigmatize social assistance while reaching a greater percentage of the poor. An expansion of social assistance through the use of conditional cash transfer programs, which are currently being piloted on a small scale in Upper Egypt, should also be further explored. ${ }^{23}$

\section{Low pension values}

Among those men and women of the older generation who were receiving pensions, the value of their pensions was seen by most to be insufficient to support their households. Although sons have traditionally been the primary form of old age support in Egypt (Yount et al. 20I2), and certainly continue to play an important role, the findings of this study suggest that in some poor households the younger generation may be too finan-

23 The CCT program is being piloted by the Ministry of Social Solidarity in collaboration with UNICEF and the American University in Cairo. See: http://www.aucegypt.edu/research/src/Pages/CCT.aspx 
cially stretched to provide significant support to their parents. ${ }^{24}$ Reliance on informal mechanisms to make up for insufficient pensions, or lack of pension access altogether, may thus still leave households quite vulnerable to unexpected circumstances or expenses. In this context, respondents did not think of informal networks as a substitute for formal social protection, but rather as a safety net to make up for income shortages after pensions were spent.

Indeed, many pension values, and particularly non-contributory pensions, are not sufficient to keep households above the poverty line. In order not to further reduce incentives to participate in social insurance, reforms should be implemented to bring contributory pension values more in line with the cost of living. Again, this was an issue addressed in Law I35 that should be further studied and acted upon by the new government. Bringing non-contributory pension levels up to the poverty line, if not above it, will require greater investment from the state. The adequacy of the proposed level of the minimum pension in Law 135 for keeping households out of poverty will also require study.

\section{Poor quality of and limited access to health insurance}

Another important element of vulnerability to unexpected life events among those interviewed in this study is the lack of access to quality health insurance. Access to health insurance at all was found to be limited to permanent or contracted public sector employees and those receiving survivor benefits. Most of the young households therefore had no access to health insurance, which several saw as a more important issue than access to social insurance due to their immediate need for health care for themselves and their young children. Among those older individuals who did have access to health insurance, the poor quality of service at public health insurance facilities was a consistent complaint, and led many to seek treatment in other facilities outside the health insurance system. With advancing age, these health care expenditures placed a considerable burden on the household. Further research focused specifically on the issue of health insurance access and quality, with the aim of identifying how coverage can be expanded and existing facilities improved, is greatly needed in this context.

\section{Lack of awareness}

Finally, although in some contexts it has been suggested that mistrust of the government may discourage workers from participating in formal

24 Yount et al. (2012) similarly find that older Egyptians in Ismailia more commonly made downward intergenerational transfers than received upward ones 
social protection schemes (Maloney 2004), this study suggests that in Egypt this is not the case. On the contrary, nearly all of those interviewed for the study, regardless of age, gender or rural/urban residence, saw the government as the most reliable and trustworthy institution for providing a retirement fund. The fact that respondents expressed their confidence in the government social insurance system shortly after the greatest political upheaval Egypt has experienced in decades, as well as during a time when accusations of corruption within the former regime were widespread, is even more striking.

In contrast, many of the respondents expressed a deep mistrust of the private sector, and not without reason. As interviews with the young generation in particular demonstrated, violations of labor law are widespread, and reportedly included lack of contracts and social insurance registration, under-reporting of salaries to social insurance, attempts to pay employer's social insurance contributions from employee's salaries, arbitrary salary reductions, deductions for sick days, and requiring employees to sign undated official resignations, effectively forfeiting their rights in case of dismissal. Faced with this level of insecurity, and in the context of high unemployment, youth were reluctant to negotiate with their employers over any kind of benefits.

Both youth and the older generation were also in a disadvantaged position because may did not know their labor rights in order to negotiate them. A significant number of respondents, particularly in the rural location and among women, were unconcerned with social insurance because they did not understand it. Even some of those who were enrolled in social insurance were unaware of their contribution levels, requirement for number of monthly contributions and that missed payments can be made up for, and what their eventual pension value might be - or even if they would get a pension. Perhaps most importantly, they did not ask.

Building an environment in which workers, and particularly young workers, are able to access the employment-based social protection benefits to which they have a right is of course a complex issue that requires, among other things, effective enforcement of labor law. However, one fairly direct measure that should be undertaken immediately is awareness campaigns. Providing workers, and, importantly, women who are out of the labor force, information about different social protection mechanisms could at least bring them to the point of knowing what benefits they should be entitled to, and hopefully spread awareness of the importance of social protection. ${ }^{25}$ For the self-employed, accurate information about their

25 Among older workers in the United States, for example, Liebman and Luttner (2010) find some evidence that fairly simple informational campaigns regarding social security can lead to changes in labor force behavior. 
eligibility for social insurance and the different contribution levels might encourage enrollment. Providing information about social assistance programs and their eligibility criteria to targeted groups is also important as a means to reach the most vulnerable, who are likely to be out of the labor market. Egypt is currently in a phase in which information sharing and citizen's rights have become more prominent issues than in any time in recent memory. This opportunity should be seized to address issues of social protection, workers' rights, and poverty reduction during this critical transition. 


\section{References}

Ahlburg, Dennis and Mona Amer. 2003. Labor Market Mobility among Egyptian Youth. Paper presented at the Research Workshop on Gender, Work and Family in the Middle East and North Africa, Mahdia Tunisia, June 8-io, 2004.

Amer, Mona and Veronique Simmonet. 2008. Labor Market Transitions in Egypt: The Impact of First Employment Status. Paper presented at the 1 $5^{\text {th }}$ Annual Economic Research Forum Conference. Cairo, Egypt, 23-25 November, 2008.

Assaad, Ragui. 2007. Institutions, Household Decisions, and Economic Growth in Egypt. In Explaining growth in the Middle East, ed. Jeffrey Nugent and Pesaran, 385-4II. Ist ed. Amsterdam: Elsevier.

Assaad, Ragui. 2009. Labor Supply, Employment and Unemployment in the Egyptian Economy, 1988 - 2006. In The Egyptian Labor Market Revisited, ed. Ragui Assaad, I - 52. Cairo: American University in Cairo Press.

Assaad, Ragui, ed. 2009. The Egyptian Labor Market Revisited. Cairo: American University in Cairo Press.

Assaad, Ragui, and Fatma El Hamidi. 2009. Women in the Egyptian Labor Market: An Analysis of Developments, 1988-2006. In The Egyptian Labor Market Revisited, ed. Ragui Assaad, II7-156. Cairo: American University in Cairo Press.

Barrientos, Armando. 20II. Social protection and poverty. International Fournal of Social Welfare 20: 240 -249.

Barrientos, Armando and David Hulme. 2009. Social protection for the poor and poorest in developing countries: Reflections on a quiet revolution. Oxford Development Studies 37 (4): 439- 456.

Barrientos, Armando, David Hulme and Andrew Shepherd. 2005. Can social protection tackle chronic poverty? The European Journal of Development Research I7 (I): 8 - 23 .

Barsoum, Ghada. 2004. The employment crisis of female graduates in Egypt: an ethnographic account. Cairo Papers in Social Science. Cairo: American University in Cairo Press.

Barsoum, Ghada, Ali Rashed and Dahlia Hassanein. 2009. When there is no Respect at Work: Job 2uality Issues for Women in Egypt's Private Sector. Gender and Work in the MENA Region Working Paper Series: Poverty, Job Quality and Labor Market Dynamics, No. 2. Cairo: Population Council.

Davis, Peter. 20Ir. Vulnerability in Rural Bangladesh: Learning from Life History Interviewes. Chronic Poverty Research Center Working Paper, No. I96. Bath, UK: CPRC. 
Dhillon, Navtej, and Tarik Yousef, eds. 2009. Generation in waiting: the unfulfilled promise of young people in the Middle East. Washington D.C.: Brookings Institution Press.

Goudge, Jane, S. Russell, L. Gilson, T. Gumede, S. Tollman and A. Mills. 2009. Illness-related impoverishment in rural South Africa: Why does social protection work for some households but not others? Fournal of International Development 21: 23I - 25I.

Helmy, Omneia. 2008. Toward a more efficient and equitable pension system in Egypt. In The Egyptian Economy: Current Challenges and Future Prospects, ed. Hanaa Kheir el-Din, 20I-234. Cairo: American University in Cairo Press.

Hoodfar, Homa. 1997. Between marriage and the market: intimate politics and survival in Cairo. Berkeley: University of California Press.

International Labor Organization (ILO). 2009. Building adequate social protection systems and protecting people in the Arab region. Thematic paper, Arab Employment Forum. Geneva: ILO.

International Labor Organization (ILO). 20I0. World Social Security Report 2010/II: Providing coverage in times of crisis and beyond. Geneva: ILO.

Kabeer, Naila. 2009. Scoping study on social protection: Evidence on impacts and future research directions. London: DFID.

Liebman, Jeffrey and Erzo Luttmer. 20Ir. Would people behave differently if they better understood social security? Evidence from a field experiment. NBER working paper No. 17287.

Loewe, Markus. 2004. Social security in Egypt: An analysis and agenda for policy reform. Economic Research Forum Working Paper no. 2024.

Maeda, Akiko, and Sameh El Saharty. 2008. Public expenditure on health in Egypt. In The Egyptian Economy: Current Challenges and Future Prospects, ed. Hanaa Kheir el-Din, 30I - 330. Cairo: American University in Cairo Press.

Maloney, William. I999. Does informality imply segmentation in urban labor markets? Evidence from sectoral transitions in Mexico. World Bank Economic Review I3 (2): 275-302.

---. 2004. Informality revisited. World Development 32 (7): II59- II78.

Moghadam, Valentine. 1998. Women, work, and economic reform in the Middle East and North Africa. Boulder Colo.: Lynne Rienner Publishers.

Moktar, May and Jackline Wahba. 2002. Informalization of Labor in Egypt. In The Egyptian Labor Market in an Era of Reform, ed. Ragui Assaad, I3I - 158. Cairo: American University in Cairo Press.

Morduch, Jonathan and Manohar Sharma. 2002. Strengthening public safety nets from the bottom up. Development Policy Review 20 (5):569- 588.

Norton, Andy, Tim Conway and Mick Foster. 2002. Social protection: Defining the field of action and policy. Development Policy Review 20 (5): $54 \mathrm{I}-567$. 
Population Council. 20I0. Survey of Young People in Egypt Final Report. Cairo: Population Council.

Sabates-Wheeler, Rachel and Naila Kabeer. 2003. Gender equality and the extension of social protection. Extension of Social Security Paper No. I6. Geneva: ILO.

Sieverding, Maia. 20II. Intergenerational social mobility and educational expansion in Egypt. Paper presented at the ISA Research Committee 28 Spring meeting, Essex, UK

Singerman, Diane. 1995. Avenues of participation: family, politics, and networks in urban quarters of Cairo. Princeton N.J.: Princeton University Press.

Social Security Administration(SSA). 20II. Social Security Programsaround the World: Africa, 20II. Washington, D.C.: Social Security Administration.

Tesliuc, Emil and Kathy Lindert. 2004. Risk and vulnerability in Guatemala: A quantitative and qualitative assessment. Social Protection Discussion Paper Series, No. 0404. Washington, D.C.: The World Bank.

van Ginneken, Wouter. 2003a. Social security for the informal sector: A new challenge for the developing countries. International Social Security Review 52: 49-69.

van Ginneken, Wouter. 2003b. Extending social security: Policies for developing countries. Extension of Social Security Paper No. I3. Geneva: ILO.

Wahba, Jackline. 2009. The Impact of Labor Market Reforms on Informality in Egypt. Gender and Work in the MENA Region Working Paper Series: Poverty, Job Quality and Labor Market Dynamics, No. 3. Cairo: Population Council.

World Bank. 2006. Opportunity, Security and Equity in the Middle East and North Africa. Spectrum Summer 2006. Washington, D.C.: World Bank.

World Bank. 2007. Arab Republic of Egypt Poverty Assessment Update. Report No. 39885 - EGT. Washington, D.C.: World Bank.

Yount, Kathryn, S. Cunningham, M. Engleman and E. Agree. 2012. Gender and material transfers between older parents and children in Ismailia, Egypt. Fournal of Marriage and Family 74: II6 - I3I. 


